\title{
Variances in Antiviral Memory T-Cell Repertoire of CD45RA- and CD62L-Depleted Lymphocyte Products Reflect the Need of Individual T-Cell Selection Strategies to Reduce the Risk of GvHD while Preserving Antiviral Immunity in Adoptive T-Cell Therapy
}

\author{
Caroline Mangare $^{a} \quad$ Sabine Tischer-Zimmermann ${ }^{a} \quad$ Agnes Bonifacius $^{a}$ \\ Sebastian B. Riese ${ }^{a} \quad$ Anna Christina Dragon ${ }^{a}$ Rainer Blasczyk ${ }^{a}$ \\ Britta Maecker-Kolhoff ${ }^{b}$ Britta Eiz-Vesper ${ }^{a}$ \\ anstitute of Transfusion Medicine and Transplant Engineering, Hannover Medical School, Hannover, Germany; \\ bepartment of Pediatric Hematology and Oncology, Hannover Medical School, Hannover, Germany
}

\section{Keywords}

Naïve T-cell depletion · Low precursor frequency · T-cell response Alloreactivity

\begin{abstract}
Introduction: Viral infections and reactivations still remain a cause of morbidity and mortality after hematopoietic stem cell transplantation due to immunodeficiency and immunosuppression. Transfer of unmanipulated donor-derived lymphocytes (DLI) represents a promising strategy for improving cellular immunity but carries the risk of graft versus host disease (GvHD). Depleting alloreactive naïve T cells $\left(T_{N}\right)$ from DLIs was implemented to reduce the risk of GvHD induction while preserving antiviral memory T-cell activity. Here, we compared two $T_{N}$ depletion strategies via CD45RA and CD62L expression and investigated the presence of antiviral memory $T$ cells against human adenovirus (AdV) and Epstein-Barr virus (EBV) in the depleted fractions in relation to their functional and immunophenotypic characteristics. Methods: T-cell responses against ppEBV_EBNA1, ppEBV_ Consensus and ppAdV_Hexon within $\mathrm{T}_{\mathrm{N}^{-}}$-depleted (CD45RA ${ }^{-}$/ $\mathrm{CD} 2 \mathrm{~L}^{-}$) and $\mathrm{T}_{\mathrm{N}}$-enriched (CD45RA ${ }^{+} / \mathrm{CD} \mathrm{L}^{+}$) fractions were quantified by interferon-gamma (IFN- $\gamma$ ) ELISpot assay after short- and long-term in vitro stimulation. T-cell frequencies and immunophenotypic composition were assessed in all
\end{abstract}

fractions by flow cytometry. Moreover, alloimmune T-cell responses were evaluated by mixed lymphocyte reaction. $\boldsymbol{R e}$ sults: According to differences in the phenotype composition, antigen-specific T-cell responses in CD45RA- fraction were up to 2 times higher than those in the CD62 $\mathrm{L}^{-}$fraction, with the highest increase (up to 4-fold) observed after 7 days for ppEBV_EBNA1-specific T cells. The CD4 ${ }^{+}$effector memory $T$ cells $\left(T_{E M}\right)$ were mainly responsible for EBV_EBNA1- and AdV_Hexon-specific T-cell responses, whereas the main functionally active $T$ cells against ppEBV_Consensus were $\mathrm{CD}^{+}$central memory $T$ cells $\left(\mathrm{T}_{\mathrm{CM}}\right)$ and $\mathrm{T}_{\mathrm{EM}}$. Moreover, comparison of both depletion strategies indicated that alloreactivity in CD45RA- was lower than that in $\mathrm{CD}^{-} \mathrm{L}^{-}$fraction. Conclusion:Taken together, our results indicate that CD45RA depletion is a more suitable strategy for generating $T_{N}$-depleted products consisting of memory $T$ cells against $p p E-$ BV_EBNA1 and ppAdV_Hexon than CD62L in terms of depletion effectiveness, T-cell functionality and alloreactivity. To maximally exploit the beneficial effects mediated by antiviral memory $\mathrm{T}$ cells in $\mathrm{T}_{\mathrm{N}}$-depleted products, depletion methods should be selected individually according to phenotype composition and CD4/CD8 antigen restriction. $\mathrm{T}_{\mathrm{N}}$-depleted DLIs may improve the clinical outcome in terms of infections, GvHD, and disease relapse if selection of pathogen-specific donor T cells is not available.

(c) 2021 The Author(s). Published by S. Karger AG, Basel

\section{karger@karger.com} www.karger.com/tmh

Karger ${ }^{\prime \prime}=$ GOPEN ACCESS
(C) 2021 The Author(s)

Published by S. Karger AG, Basel

This is an Open Access article licensed under the Creative Common Attribution-NonCommercial-4.0 International License (CC BY-NC) (http://www.karger.com/Services/OpenAccessLicense), applicable to the online version of the article only. Usage and distribution for commercial purposes requires written permission.
Correspondence to:

Britta Eiz-Vesper, eiz-vesper.britta @ mh-hannover.de 


\section{Introduction}

Hematopoietic stem cell transplantation and solid organ transplantation are sometimes associated with infectious complications due to conditioning and immunosuppression. Post-transplant mortality is caused by graft versus host disease (GvHD) in 12\% of cases and by infections in $11 \%$ of cases $[1,2]$. Viral infections and reactivations frequently encountered among immunocompromised patients mainly involve endogenous herpesviruses, such as cytomegalovirus (CMV), Epstein-Barr virus (EBV) and human herpesvirus 6 (HHV6), and lytic pathogens, such as human adenovirus (AdV) and BK polyomavirus. EBV persistently infects more than $90 \%$ of the human adult population and can cause infectious mononucleosis, which is highly sympomatic $[3,4]$. EBV is categorised into 3 latency types and has a potent B-cell growth-transforming ability linked to various EBV-associated tumours, including endemic Burkitt lymphoma, Hodgkin lymphoma and diffuse large B-cell lymphoma, and is associated with post-transplant lymphoproliferative disease in immunocompromised patients [5-8]. Among viral infections, AdV is the most common infectious complication in children with reported incidences varying from 6 to $28 \%$ after hematopoietic stem cell transplantation [9] followed by up to $6 \%$ in adults $[10,11]$. Reduction of immunosuppression is a standard approach to restoring antiviral immunity in these patients, while antiviral drug therapy is administered to prevent or control viral infection or reactivation [12]. Downstream complications, adverse drug reactions and the appearance of disease-resistant mutants are major limitations of these drugs.

During the past years, the therapeutic potential of virus-specific memory T cells (VSTs) was demonstrated using unmanipulated donor lymphocyte infusions (DLIs) from seropositive donors. However, application of DLIs resulted in the same cases in the development of severe GvHD due to the presence of alloreactive T cells in the naïve T-cell $\left(\mathrm{T}_{\mathrm{N}}\right)$ compartment, which accounted for up to $10 \%$ of circulating $\mathrm{T}$ cells [13]. These limitations led to the development of methods for VST-enriched products, which were shown to have beneficial therapeutic effects against severe viral infections, particularly CMV, EBV and $\mathrm{AdV}$, and, consequently, this treatment approach has now been extended to other viral infections $[14,15]$. VSTs can be isolated via an interferon-gamma (IFN- $\gamma$ )-based cytokine capture system, directly selected via reversible peptide-major histocompatibility complex (pMHC) multimers $[16,17]$, or generated by in vitro expansion, starting with a small number of antiviral precursor $\mathrm{T}$ cells in the presence of specific target antigens [18]. Even so, the potential to generate VSTs by these promising strategies is limited by conditions required for effective stimulation and enrichment and a good knowledge of immunodominant viral proteins and epitopes and the availability of good manufacturing practice quality grade antigens. Furthermore, low immunogenicity of some T-cell epitopes (e.g., Epstein-Barr nuclear antigen 1, EBNA1) also causes problems [19]. Consequently, strategies to refine DLIs through selective $\mathrm{T}_{\mathrm{N}}$ depletion were developed to obtain antiviral memory $\mathrm{T}$-cell products with the potential to protect patients from viral infection/reactivation while reducing the risk of GvHD occurrence [20-22].

Antiviral memory $\mathrm{T}$ cells are a heterogeneous population differing in phenotype, function and protective capacity against different viruses $[23,24]$, but their contribution to alloreactivity is unknown. Strong correlations between the frequency, the phenotypic profile and the protective efficacy of antiviral $\mathrm{T}$ cells have been described [25]. These characteristics may vary among individuals, resulting in different strengths of antiviral responses. We and other researchers demonstrated that CMV-specific $\mathrm{T}$-cell responses are dependent on $\mathrm{CD}^{+}$late effector memory RA T cells $\left(\mathrm{T}_{\mathrm{EMRA}}\right)$ [26, 27], while other studies reported that central memory $\mathrm{T}$ cells $\left(\mathrm{T}_{\mathrm{CM}}\right)$ are responsible for immune responses against hepatitis $\mathrm{C}$ virus $(\mathrm{HCV})$ and effector memory $\mathrm{T}$ cells $\left(\mathrm{T}_{\mathrm{EM}}\right)$ for human immunodeficiency virus (HIV) $[27,28] . \mathrm{CD}^{+}$and $\mathrm{CD}^{+}$ antiviral memory $\mathrm{T}$-cell functions have also been described in different viral antigen settings. $\mathrm{CD} 4^{+}$-specific $\mathrm{T}$ cells are reportedly responsible for the alleviation of Dengue virus [29], West Nile virus [30], Zika virus [31] and Friend virus [32], and $\mathrm{CD}^{+}{ }^{-}$-specific T cells for lymphocytic choriomeningitis virus [33], influenza A virus [34], CMV [27] and some EBV epitopes from latent membrane proteins (LMP), LMP2 and LMP1 $[35,36]$. Therefore, as new T-cell therapy modalities enter into clinical trials, it is important to understand the precise contribution of $\mathrm{CD}^{+}$and $\mathrm{CD}^{+}$naïve and memory $\mathrm{T}$ cells and the circumstances that predict a greater likelihood of success in improving antiviral T-cell responses and reducing the risk of GvHD.

T-cell phenotypes are characterised according to their cell surface markers. $\mathrm{T}_{\mathrm{N}}$ are $\mathrm{CD} 45 \mathrm{RA}^{+} / \mathrm{CD} 6 \mathrm{~L}^{+}, \mathrm{T}_{\mathrm{CM}}$ $\mathrm{CD} 4 \mathrm{RA}^{-} / \mathrm{CD} 62 \mathrm{~L}^{+}, \mathrm{T}_{\mathrm{EM}} \mathrm{CD} 4 \mathrm{RA}^{-} / \mathrm{CD} 62 \mathrm{~L}^{-}$, and $\mathrm{T}_{\mathrm{EMRA}}$ $\mathrm{CD}^{2} 5 \mathrm{RA}^{+} / \mathrm{CD} 62 \mathrm{~L}^{-}$[37]. These differences allow for selective $\mathrm{T}_{\mathrm{N}}$ depletion using CD45RA and CD62L microbeads as major $\mathrm{T}_{\mathrm{N}}$ depletion strategies. CD45RA depletion has been the subject of most clinical trials performed to date, in spite of the subsequent loss of $\mathrm{CD} 8^{+} \mathrm{T}$ cells and $\mathrm{T}_{\text {EMRA }}[21,26,35,36]$. On the other hand, $\mathrm{T}_{\mathrm{CM}}$ are lost in CD62L-based depletion. Nevertheless, precise information about the contribution of CD45RA ${ }^{+/-}, \mathrm{CD} 6 \mathrm{~L}^{+/-}$and $\mathrm{CD} 4 / \mathrm{CD} 8 \mathrm{~T}$-cell proportion against various viral antigens has not been described. In a previous study, we demonstrated that the magnitude of CMV-specific T-cell responses depends on the immunophenotypic composition 
of the lymphocyte product [26]. T-cell fractions that had a higher proportion of $\mathrm{CD} 8^{+} \mathrm{T}_{\mathrm{EMRA}}$ elicited significantly higher T-cell responses against ppCMV_pp65 and ppCMV_IE1. We extended this approach to the current study, which aimed to elucidate the most efficient $\mathrm{T}_{\mathrm{N}}$ depletion strategy in terms of preserving functional antiviral memory $\mathrm{T}$ cells with low precursor frequencies and their protective capacity while using human AdV and EBV as viral targets of interest. Moreover, we examined the potency of alloreactive responses among the $\mathrm{T}$-cell fractions to detect $\mathrm{T}$-cell subsets with the least alloreactivity.

\section{Materials and Methods}

\section{Ethics Statement and Donors}

All experiments were performed with residual blood samples from platelet apheresis disposable kits used for routine platelet collection from regular healthy blood donors of the Institute of Transfusion Medicine and Transplant Engineering at the Hannover Medical School (MHH). Informed consent as approved by the Ethics Committee of the MHH was obtained from all donors. All donors belong to alloCELL registry (www-allcell.com) and were pretested for EBV and AdV serology as described previously using commercially available IgG Western blot and IgG ELISA kits (recomLine EBV IgG and alphaWell Adenovirus IgG ELISA, both from Mikrogen) according to the manufacturer's instructions [38, 39].

Isolation of Peripheral Blood Mononuclear Cells and T Cells

Isolation of the different T-cell fractions was performed as described previously $[26,40]$. Briefly, peripheral blood mononuclear cells (PBMCs) were isolated from EBV- and AdV-seropositive donors by discontinuous-gradient centrifugation. Untouched $\mathrm{CD}^{+} \mathrm{T}$ cells were enriched by magnetic cell sorting (MACS) using the Pan T-cell isolation kit (Miltenyi Biotec) according to the manufacturer's instructions. $\mathrm{CD}^{+} \mathrm{T}$ cells were collected as flow-through and bead-loaded non-T cells were collected from columns as eluate. Further, the isolated $\mathrm{CD}^{+} \mathrm{T}$ cells were used for $\mathrm{T}_{\mathrm{N}}$ depletion using CD45RA or CD62L immunomagnetic microbeads according to the manufacturer's instructions (Miltenyi Biotec). Negative fractions (flow-through) and positive fractions (eluate) were collected by LS columns (Miltenyi Biotec) and termed as follows: memory/negative fractions (CD45RA_NF and CD62L_NF) and naïve/positive fractions (CD45RA_PF and CD62L_PF).

Short- and Long-Term in vitro Stimulation Assays to Assess $E B V$ - and $A d V$-Specific T-Cell Response in $T_{N}$-Depleted and $T_{N}$-Enriched Fractions

EBV- and AdV-specific memory $\mathrm{T}$ cells in $\mathrm{T}_{\mathrm{N}}$-depleted and -enriched fractions were evaluated by phenotypic and functional assays. Briefly, freshly isolated CD45RA and CD62L T-cell fractions (CD45RA_NF/PF and CD62L_NF/PF) were rested overnight $\left(37^{\circ} \mathrm{C}, 5 \% \mathrm{CO}_{2}\right)$ at a density of $1 \times 10^{7}$ cells/well (24-well plate, Sarstedt) prior to short- (1 day) or long-term (7 days) in vitro stimulation. $1 \times 10^{7} \mathrm{CD} 3$-depleted PBMCs/well (24-well plate) were loaded overnight with the peptide pool (pp) ppEBV_EBNA1, ppEBV_Consensus or ppAdV_Hexon, respectively $(1 \mu \mathrm{g} /$ per peptide/mL; Miltenyi Biotec). On day $1, \mathrm{~T}$ cells at a density of $5 \times 10^{5}$ were co-cultured with $5 \times 10^{4}$ antigen-loaded CD3-depleted PBMCs in T-cell culture medium (TCM) RPMI1640 (Lonza) with
$10 \%$ heat-inactivated human $\mathrm{AB}$ serum (C.C.pro) supplemented with $50 \mathrm{U} / \mathrm{mL}$ interleukin (IL)-2, $10 \mathrm{ng} / \mathrm{mL}$ IL-7 and $10 \mathrm{ng} / \mathrm{mL}$ IL15 (all PeproTech) over 7 days.

Detection of EBV-and AdV-Specific T-Cell Response by IFN- $\gamma$ Enzyme-Linked ImmunoSpot (ELISpot) Assay

Functionality of the different T-cell fractions was analysed by a target cell-dependent IFN- $\gamma$ ELISpot assay after short- and longterm in vitro stimulation, as previously described $[38,41]$. On day 0 (short-term stimulation) as well as on day 6 (long-term stimulation), $1 \times 10^{7} \mathrm{CD} 3$-depleted PBMCs/well (24-well plate) were loaded overnight either with ppEBV_EBNA1, ppEBV_Consensus or ppAdV_Hexon ( $1 \mu \mathrm{g}$ per peptide/mL) in TexMACS medium (Miltenyi Biotec) followed by co-cultivation with the different $\mathrm{T}$-cell fractions (effector cells) in an effector to target (E:T) ratio of 1:1 and 5:1 in pre-coated anti-IFN- $\gamma$ EliSpot plates (Lophius Biosciences). Negative and positive controls were carried out by using either solitary medium, effector $\mathrm{T}$ cells and target cells alone or $1 \mu \mathrm{g} / \mathrm{mL}$ staphylococcal enterotoxins B (SEB, Sigma Aldrich). IFN- $\gamma$ secretion was detected using streptavidin-alkaline phosphatase (Mabtech) and revealed by 5-13 bromo-4-chloro-3-indolyl phosphate/nitroblue tetrazolium (BCIP/NBT Liquid Substrate, Sigma-Aldrich). Spots were counted using AID EliSpot 8.0 on an AID iSpot spectrum reader system (both from AID). Resultant findings are indicated as number of spots per well (spw). The cutoff for positive response was at least 2 times higher than the negative control.

\section{Alloreactivity in Mixed Lymphocyte Reaction Cultures}

T-cell-mediated alloreactivity was measured in all T-cell fractions (CD45RA_NF/PF and CD62L_NF/PF) by allogeneic mixed lymphocyte reaction (MLR) assay. T-cell fractions (effector cells) were labelled with carboxyfluorescein succinimidyl ester (CFSE, ThermoFisher Scientific) at a final concentration of $4 \mu \mathrm{M}$. At a cell density of $1 \times 10^{5}$, CFSE-labelled T-cell fractions (responder) were co-cultured with irradiated $(1 \times 30 \mathrm{~Gy})$ HLA-matched autologous or HLA-mismatched pooled PBMCs (stimulator, PBMCs from 3 to 5 donors) at an E:T ratio of 1:1 in TCM supplemented with $50 \mathrm{U} / \mathrm{mL}$ IL-2, $10 \mathrm{ng} / \mathrm{mL}$ IL-7 and $10 \mathrm{ng} / \mathrm{mL}$ IL-15. As negative controls, target or effector cells were cultured alone, while T-cell fractions co-cultured with anti-CD3/CD28 beads (ThermoFisher Scientific) in a 1:1 ratio served as positive control. After 7 days, Tcell frequencies and phenotype were analysed by flow cytometry. Proliferation of CFSE-labelled T-cell fractions co-cultured with HLA-mismatched allogeneic PBMCs was compared with proliferation in relation to HLA-matched autologous controls determined by CFSE dilution. The difference in T-cell proliferation between the autologous and allogeneic setting was used as readout for alloreactivity.

\section{Flow Cytometry Analysis}

$\mathrm{T}$-cell frequencies, CD4/CD8 ratio and the phenotypic T-cell composition were assessed by flow cytometry (FACSCanto 10c, FACSDiva V8.0.1 software, BD Biosciences) directly after isolation and $\mathrm{T}_{\mathrm{N}}$ depletion (PBMCs, $\mathrm{CD}^{+} \mathrm{T}$ cells and CD45RA_NF/PF, CD62L_NF/PF) as well as after long-term in vitro stimulation (day 6). Assessment of T-cell frequency, CD4/CD8 ratio and phenotypic T-cell composition was carried out using the following monoclonal antibodies (mAbs): anti-CD3-Peridinin-Chlorophyll (PerCP), anti-CD8Alexa Fluor (AF) 700, anti-CD45RA-brilliant violet (BV) 510 and anti-CD62L-allophycocyanin/Cyanin 7 (APC/ Cy7) (all BioLegend). Gating was carried out in accordance with the light scatter properties of lymphocytes and $\mathrm{CD}^{+} \mathrm{T}$-cell populations. With at least 30,000 events in the $\mathrm{CD}^{+}$gate, the focus of the gating strategy was set on the $\mathrm{CD} 3^{+}, \mathrm{CD}^{+} \mathrm{CD}^{+}$and $\mathrm{CD} 3^{+} \mathrm{CD} 4^{+}$ 
Table 1. Assessment of cellular composition including T-cell frequencies and phenotypes among healthy blood donors following naive T-cell depletion

\begin{tabular}{lclcrrr}
\hline T-cell subset & PBMCs & CD3 & \multicolumn{1}{l}{ CD45RA_NF } & \multicolumn{1}{l}{ CD62L_NF } & \multicolumn{1}{l}{ CD45RA_PF } & CD62L_PF \\
\hline $\mathrm{CD}^{+}, \%$ & $64.4(47.4-74.9)$ & $96.0(95.2-97.3)$ & $97.5(94.8-99.7)$ & $96.2(94.2-98.3)$ & $94.9(91.8-97.9)$ & $96.0(94.9-99.5)$ \\
$\mathrm{T}_{\mathrm{N}}, \%$ & $34.0(16.4-49.3)$ & $47.0(33.1-58.7)$ & $0.2(0.04-0.48)$ & $13.5(0.54-45.1)$ & $72.7(65.2-78.4)$ & $57.6(39.6-64.0)$ \\
$\mathrm{T}_{\mathrm{CM}}, \%$ & $20.7(9.63-30.0)$ & $24.3(18.3-31.1)$ & $57.5(52.1-62.7)$ & $2.5(0.11-7.68)$ & $0.2(0.01-0.43)$ & $35.6(26.0-56.0)$ \\
$\mathrm{T}_{\mathrm{EM}}, \%$ & $21.5(15.3-30.7)$ & $18.6(10.1-29.6)$ & $42.1(37.2-47.6)$ & $63.8(23.5-85.0)$ & $0.1(0.01-0.28)$ & $3.11(1.02-6.49)$ \\
$\mathrm{T}_{\mathrm{EMRA}}, \%$ & $23.9(11.2-48.4)$ & $10.2(5.79-14.9)$ & $0.14(0.042-0.31)$ & $20.2(11.6-27.4)$ & $27.0(21.0-34.8)$ & $4.0(0.98-10.6)$ \\
$\mathrm{CD} 4^{+}, \%$ & $84.33(78.6-91.1)$ & $71.62(65-79.4)$ & $83.93(74.4-89.5)$ & $64.35(57.0-83.3)$ & $65.85(60.6-75.7)$ & $23.28(10.4-29.7)$ \\
$\mathrm{CD} 8^{+}, \%$ & $15.67(8.92-21.4)$ & $28.38(20.6-35.0)$ & $16.07(10.5-25.6)$ & $5.65(16.7-43.0)$ & $34.15(24.3-39.4)$ & $24.66(3.6-46.6)$ \\
$\mathrm{CD} 4 / 8$ ratio & 5.38 & 2.52 & 5.22 & 1.81 & 1.93 & 0.9 \\
\hline
\end{tabular}

T-cell frequencies and phenotypes in different T-cell fractions, as determined by flow cytometry (mean, range; $n=6$ ) in naive T-celldepleted and naïve-enriched T-cell fractions. T-cell frequencies are expressed as \% mean and range of CD $3^{+}, \mathrm{CD}^{+}$, and CD8 ${ }^{+} \mathrm{T}$ cells.

T cells in order to assess their phenotype using CD45RA and CD62L as specific markers. Data were analysed by using the FlowJo V10.6.1 software (Becton Dickinson).

\section{Statistics}

Statistical analysis was performed using the Prism v8.0 software (GraphPad). The results are displayed as mean, range \pm standard deviation (SD). Generated data were analysed using non-parametric Mann-Whitney test and Wilcoxon matched-pairs signed-rank test $\left({ }^{*} p<0.05,{ }^{* *} p<0.01\right.$, not significant $\left.[\mathrm{ns}]\right)$.

\section{Results}

\section{Efficacy of $T_{N}$ Depletion Using Immunomagnetic CD45RA and CD62L Microbeads}

Small-scale experiments with PBMCs from healthy blood donors were performed to assess the feasibility of $\mathrm{T}_{\mathrm{N}}$-depleted DLI using CD45RA and CD62L microbeads. The CD45RA_NF/PF as well as CD62L_NF/PF fractions were analysed for purity and phenotype (shown in Fig. 1). The mean $\mathrm{CD}^{+}$T-cell frequency in CD45RA_NF and CD62L_NF was 97.5 and $96.2 \%, 83.9$ and $64.3 \%$ for $\mathrm{CD}^{+}$ T-cell subsets, and 16.1 and $35.7 \%$ for $\mathrm{CD}^{+}{ }^{+} \mathrm{T}$-cell subsets, respectively (shown in Table 1, Fig. 1A). Hence, the depletion of $\mathrm{T}_{\mathrm{N}}$ led to a significant reduction of $\mathrm{CD} 8^{+}$ T cells in CD45RA_NF (CD4/CD8 ratio 5.2, $p<0.01$ ), but not in CD62L_NF (CD4/CD8 ratio 1.8, shown in Fig. 1A). Furthermore, the proportion of $\mathrm{CD}^{+}$and $\mathrm{CD}^{+} \mathrm{T}$ cells was significantly different between CD45RA and CD62L fractions (NF/PF, $p<0.05)$. Regarding the memory fractions gated on $\mathrm{CD}^{+} \mathrm{T}$ cells, CD45RA_NF consisted mainly of $\mathrm{T}_{\mathrm{CM}}$ (mean 57.5\%) and $\mathrm{T}_{\mathrm{EM}}$ (mean 42.1\%), whereas CD62L_NF consisted mainly of $\mathrm{T}_{\mathrm{EM}}$ (mean $63.8 \%$ ) and $\mathrm{T}_{\text {EMRA }}$ (mean 20.2\%), with $13.5 \% \mathrm{~T}_{\mathrm{N}}$ contamination (shown in Fig. 1B). Conversely, in the naïve fractions, CD45RA_PF contained predominantly $\mathrm{T}_{\mathrm{N}}$ and $\mathrm{T}_{\mathrm{EMRA}}$, while CD62L_PF contained mainly $\mathrm{T}_{\mathrm{N}}$ and $\mathrm{T}_{\mathrm{CM}}$ with only a small proportion of $\mathrm{T}_{\mathrm{EM}}$ and $\mathrm{T}_{\mathrm{EMRA}}$. Overall, CD45RA microbeads proved to be more suitable for $T_{N}$ depletion, because of a higher purity of the memory T-cell fraction (NF).

\section{Functional Signatures of Antiviral Memory T Cells} within CD45RA_NF/PF and CD62L_NF/PF Fractions

Based on observations of viral infections in vivo, there is a strong correlation between the phenotypic profiles of antiviral T cells, which dictate the magnitude of T-cell responses, and their protective efficacy against different viruses $[25,26,42]$. With respect to low-frequency antiviral $\mathrm{T}$ cells, we evaluated EBV- and AdV-specific T-cell responses in $\mathrm{T}_{\mathrm{N}^{-}}$depleted and $\mathrm{T}_{\mathrm{N}}$-enriched $\mathrm{T}$-cell fractions following short-term (1 day; shown in Fig. 2A, B and Fig. $3 \mathrm{~A}-\mathrm{C}$ ) and long-term in vitro stimulation (7 days; shown in Fig. 3A-C) using a target cell-dependent IFN- $\gamma$ ELISpot assay as the readout system. T-cell responses were evaluated in the $\mathrm{T}_{\mathrm{N}}$-depleted fractions since these fractions were comprised of memory T-cells depending on the depletion strategy used, and it was anticipated that they would elicit antiviral T-cell responses. Overall, after short-term stimulation, T-cell responses, measured as number of spw, were highest against the ppEBV_Consensus among all T-cell fractions with CD45RA_NF showing the highest T-cell response (mean 319 spw, range 118$790 \mathrm{spw}$ ). On the other hand, T-cell responses against ppEBV_EBNA1 and ppAdV_Hexon following shortterm stimulation were absent or low, with the lowest number of spots detected in CD62L_PF (ppEBV_EBNA1, mean 10 spw, range 0-52 spw; ppAdV_Hexon mean 7 spw, range $0-16 \mathrm{spw}$ ). However, the highest T-cell responses for both peptide pools were detected among CD45RA_NF, with a mean of $42 \mathrm{spw}$ (ppEBV_EBNA1) and 39 spw (ppAdV_Hexon), respectively, as shown in Figure 2A, B. Low-frequency T cells against EBV_EBNA1 and AdV_Hexon were considerably better detectable by 
A

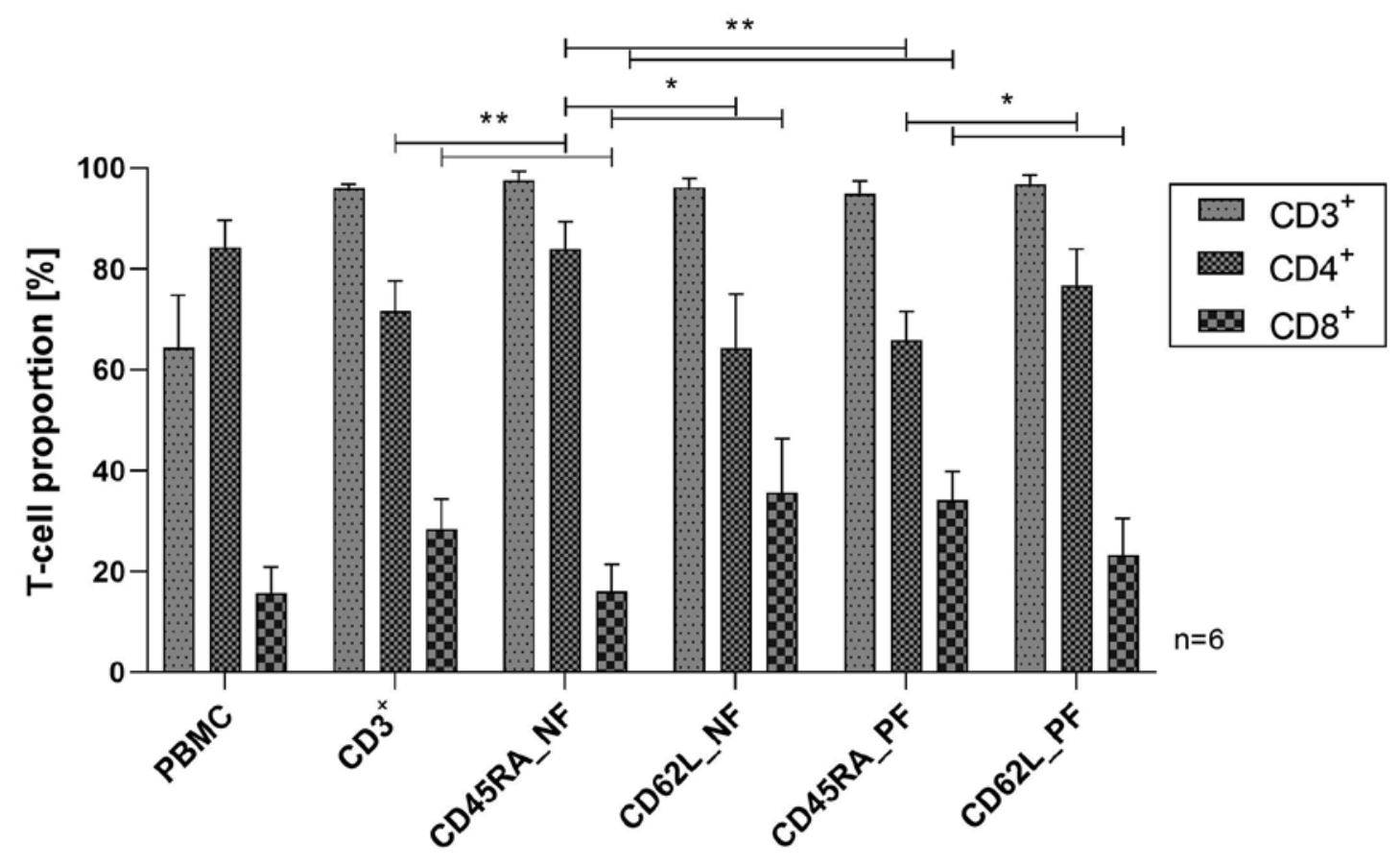

B

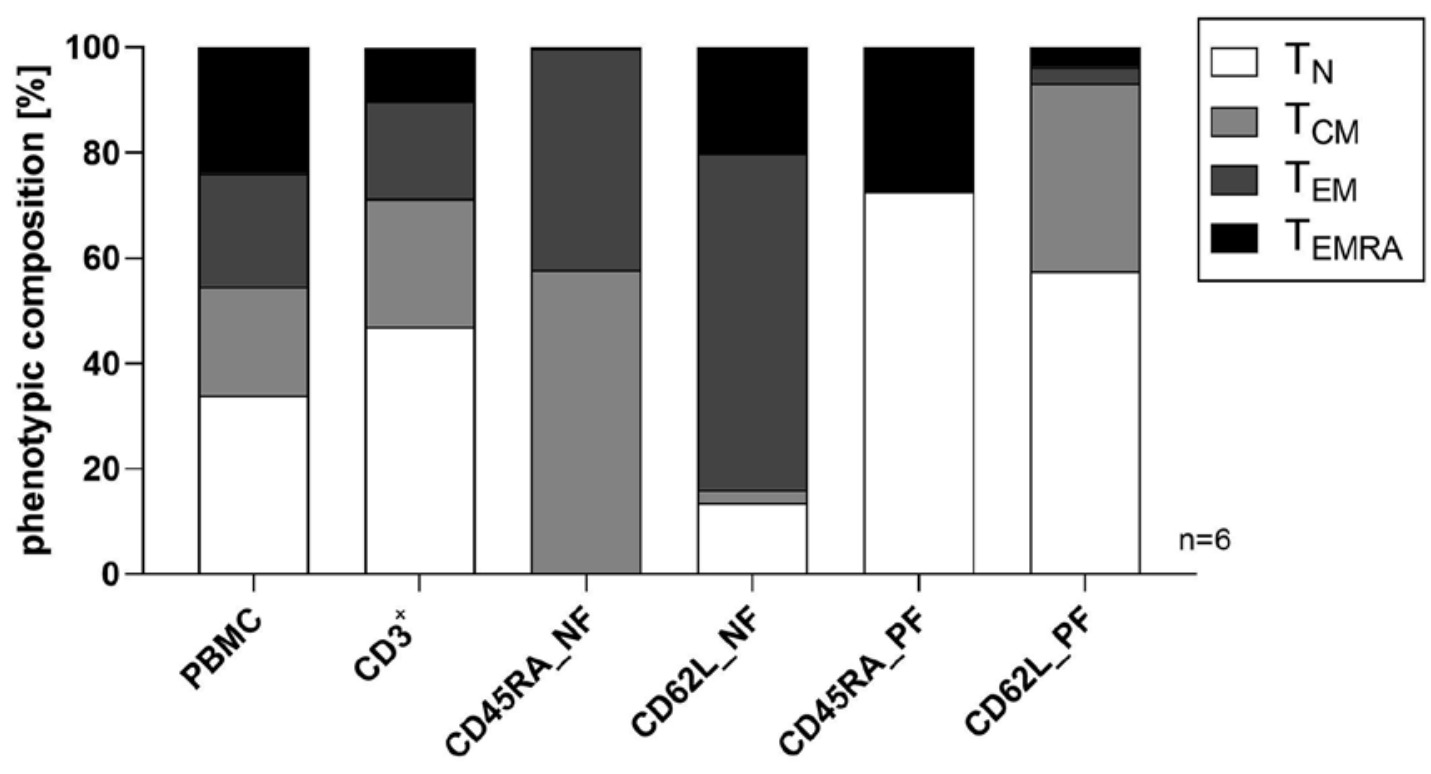

Fig. 1. Evaluation of T-cell frequencies and phenotypes following $\mathrm{T}_{\mathrm{N}}$ depletion. $\mathrm{CD}^{+} \mathrm{T}$ cells were isolated from PBMCs of 6 healthy blood donors followed by $\mathrm{T}_{\mathrm{N}}$ depletion using CD45RA and CD62L microbeads. Immunophenotypic analysis was performed by flow cytometry before and after depletion. A Frequencies of $\mathrm{CD}^{+}$, $\mathrm{CD}^{+}$and $\mathrm{CD}^{+} \mathrm{T}$ cells within the different $\mathrm{T}$-cell fractions. B T-cell phenotypes were described as: naïve $\left(\mathrm{T}_{\mathrm{N}}\right.$ : $\left.\mathrm{CD} 45 \mathrm{RA}^{+} \mathrm{CD} 6 \mathrm{~L}^{+}\right)$, central memory $\left(\mathrm{T}_{\mathrm{CM}}\right.$ : CD45RA-CD62 $\left.\mathrm{L}^{+}\right)$, effector memory $\left(\mathrm{T}_{\mathrm{EM}}\right.$ : $\left.\mathrm{CD} 4 \mathrm{RA}^{-} \mathrm{CD} 62 \mathrm{~L}^{-}\right)$and late effector memory $\mathrm{T}$ cells re-expressing
CD45RA ( $\mathrm{T}_{\mathrm{EMRA}}$ : CD45RA $\left.{ }^{+} \mathrm{CD}_{62} \mathrm{~L}^{-}\right)$. The isolated fractions consisted mainly of CD45RA_PF ( $\mathrm{T}_{\mathrm{N}}$ and $\left.\mathrm{T}_{\mathrm{EMRA}}\right)$ and CD45RA_NF $\left(\mathrm{T}_{\mathrm{CM}}\right.$ and $\left.\mathrm{T}_{\mathrm{EM}}\right)$ as well as CD62L_PF $\left(\mathrm{T}_{\mathrm{N}}\right.$ and $\left.\mathrm{T}_{\mathrm{CM}}\right)$ and CD62L_NF $\left(\mathrm{T}_{\mathrm{EMRA}}\right.$ and $\left.\mathrm{T}_{\mathrm{EM}}\right)$. Data represent the means of 6 donors. Memory/ negative fractions: CD45RA_NF and CD62L_NF, naïve/positive fractions: CD45RA_PF and CD62L_PF. Results are displayed as means \pm SD. Asterisks indicate statistically significant differences between T-cell fraction in the T-cell proportion (Mann-Whitney test, $* p<0.05, * * p<0.01)$. 
A

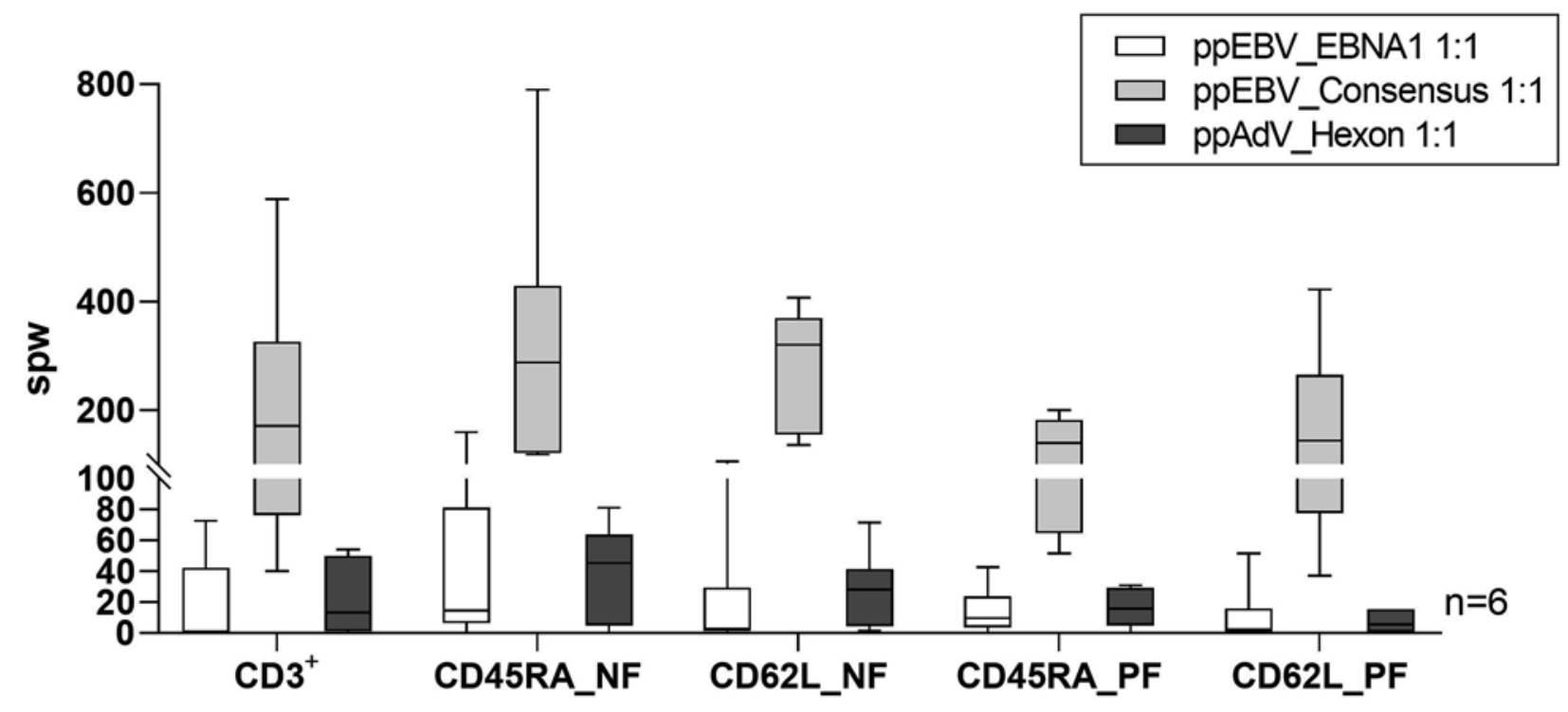

B
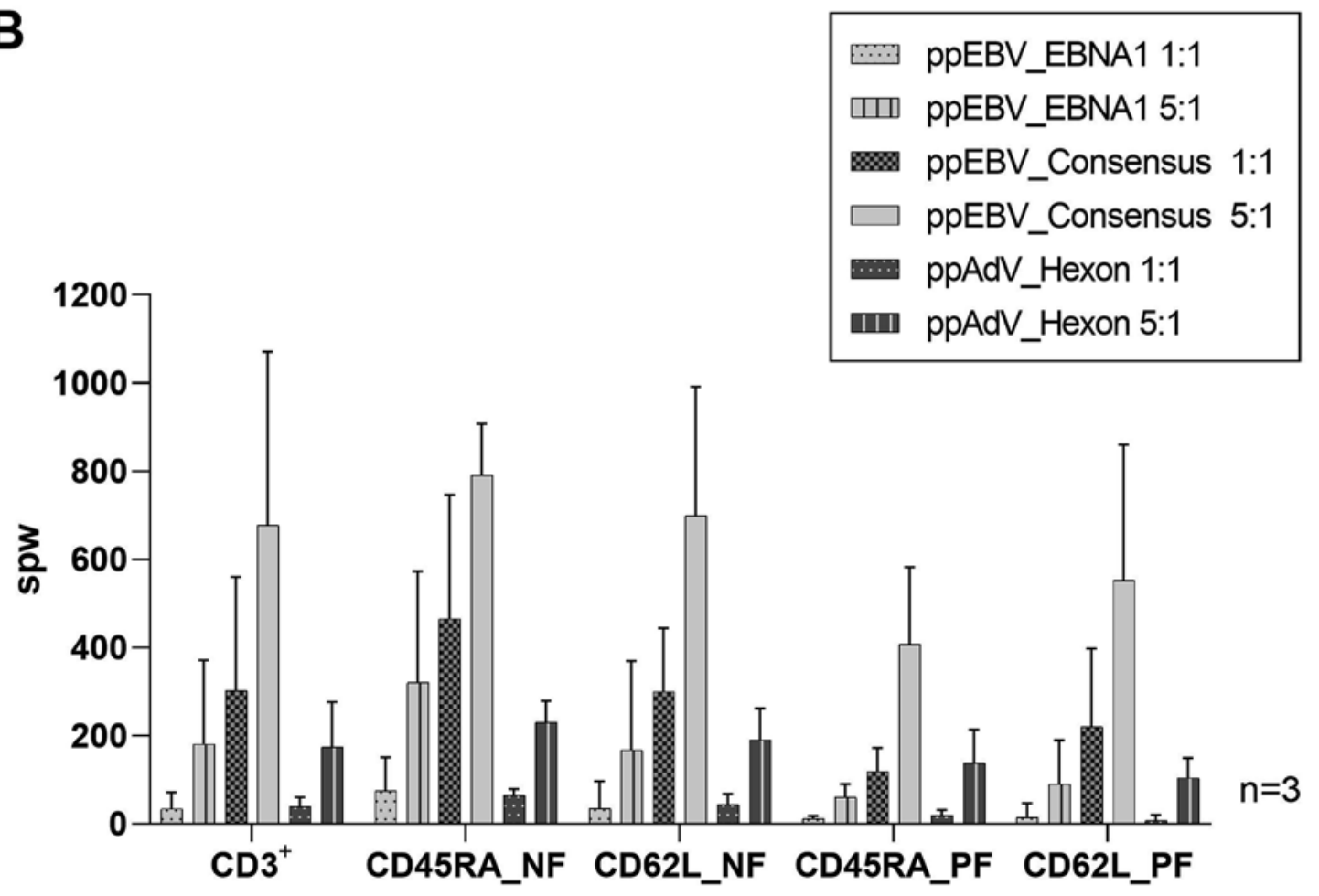

Fig. 2. T-cell responses to ppEBV_EBNA1, ppEBV_Consensus and ppAdV_Hexon after short-term in vitro stimulation using IFN- $\gamma$ ELISpot assay. Antiviral T-cell responses were determined by target cell-dependent IFN- $\gamma$ ELISpot assay. $\mathrm{CD}^{+} \mathrm{T}$ cells were isolated from PBMCs of 6 healthy blood donors followed by $\mathrm{T}_{\mathrm{N}}$ depletion using CD45RA and CD62L microbeads. Antigen-specific T-cell responses detected by IFN- $\gamma$ ELISpot assay after shortterm in vitro stimulation (1 day) with antigen-loaded CD3-de- pleted PBMCs (target cells) loaded with either ppEBV_EBNA1, ppEBV_Consensus or ppAdV_Hexon $(1 \mu \mathrm{g}$ per peptide/mL) at an E:T ratio of $1: 1(n=6)(\mathbf{A})$ and at an E:T ratio of $1: 1$ and $5: 1(n=$ 3) (B). T-cell fractions cultured alone served as control. Results are displayed as means \pm SD and were calculated by subtracting the observed values from the control. Memory/negative fractions: CD45RA_NF and CD62L_NF, naïve/positive fractions: CD45RA_ PF and CD62L_PF; spw, spot per well; pp, peptide pool. 
using an E:T ratio of 5:1 for IFN- $\gamma$ ELISpot assay (shown in Fig. 2B). Since T-cell responses against ppEBV_EBNA1 and ppAdV_Hexon were low or not detectable after short-term stimulation, long-term stimulation of the different T-cell fractions was also performed. Longer stimulation induced a high increase in antiviral T-cell responses against ppEBV_EBNA1 and ppAdV_Hexon in CD45RA_NF, with maximum mean responses of 306 $(p<0.05)$ and 104 spw, respectively. Additionally, longterm stimulation produced a significant increase in T-cell responses in CD62L_PF, which had shown no or low $\mathrm{T}$-cell responses after short stimulation (shown in Fig. 3A, $p<0.01$, and Fig. 3C). On the other hand, only marginal differences in T-cell responses against ppEBV_Consensus between short- and long-term stimulation were observed (shown in Fig. 3B); the highest T-cell response occurred in CD62L_PF (mean of 355 spw). Furthermore, the amplitude of antiviral T-cell response, as detected by IFN- $\gamma$ ELISpot assay, correlated nicely with the total cell counts (data not shown). However, the lowest fold changes occurred in CD45RA_PF followed by CD62L_NF. This might be due to presence of $\mathrm{T}_{\mathrm{EMRA}}$, which have low proliferative capacities [25], as shown in online suppl. Figure S1A (see www.karger.com/doi/10.1159/000516284 for all online suppl. material).

\section{Phenotypic Plasticity of Antiviral T Cells within CD45RA_NF/PF and CD62L_NF/PF following Antigenic Stimulation}

Here, we evaluated the immunophenotypic composition of the different T-cell fractions after short- and long-term antigenic stimulation. Stimulation drove $\mathrm{T}$ cells towards a more differentiated phenotype, and a substantial increase in $\mathrm{T}_{\mathrm{EM}}$ was observed within all $\mathrm{T}$-cell fractions. Memory $\mathrm{T}$ cells $\left(\mathrm{T}_{\mathrm{EM}}\right.$ and $\left.\mathrm{T}_{\mathrm{CM}}\right)$ are known to be more efficient producers of IFN- $\gamma$ than $T_{N}$ following stimulation [43]. This is also reflected by the antiviral T-cell response detected by target cell-dependent IFN- $\gamma$ ELISpot assay after short- and longterm stimulation [43]. Following stimulation with ppEBV_EBNA1 and ppAdV_Hexon, $\mathrm{T}_{\mathrm{EM}}$ frequencies increased to a mean of 74.9 and $67.4 \%$ in CD45RA_NF, and to a mean of 79.8 and $76.9 \%$, respectively, in
CD62L_NF (shown in online suppl. Fig. S1A). On the other hand, T cells stimulated with ppEBV_Consensus resulted in a slightly higher proportion of $\mathrm{T}_{\mathrm{CM}}$ within CD62L_PF (mean of 44.7\%) and higher proportions of $\mathrm{T}_{\mathrm{EM}}$ in the other T-cell fractions (shown in online suppl. Fig. S1A). Following stimulation with ppEBV_Consensus, $\mathrm{CD}^{+} \mathrm{T}$-cell frequencies increased in all T-cell fractions except CD45RA_NF, while CD4 ${ }^{+}$T-cell frequencies increased following stimulation with ppEBV_EBNA1 and ppAdV_Hexon in all fractions except CD62L_NF as compared to the control (effector cells co-cultured with unloaded target cells, shown in online suppl. Fig. S1B). Overall, ppEBV_EBNA1 and ppAdV_Hexon induced a shift towards $\mathrm{CD}^{+} \mathrm{T}$ cells and $\mathrm{T}_{\mathrm{EM}}$, while after expansion with ppEBV_Consensus, $\mathrm{CD}^{+} \mathrm{T}$ cells, $\mathrm{T}_{\mathrm{CM}}$ and $\mathrm{T}_{\mathrm{EM}}$ phenotype predominated (shown in online suppl. Fig. S1A, B).

\section{Contributions of CD45RA_NF/PF and CD62L_NF/ PF Fractions in Alloreactive $\mathrm{CD}^{+}$and $C D 8^{+}{ }^{-}$-Cell Responses}

Previous studies provided evidence that alloreactive lymphocytes are not only restricted to the naïve T-cell pool, but that they could also be present in memory T-cells compartment due to subliminal pre-sensitization following blood transfusion or pregnancy $[44,45]$. Therefore, we analysed alloreactivity induced by the different $\mathrm{T}$-cell subsets in the previously described $\mathrm{T}_{\mathrm{N}}$-depleted and enriched T-cell fractions (responders) co-cultured with HLA-mismatched allogeneic PBMCs (stimulators) and compared with proliferation in relation to HLA-matched autologous controls determined by CFSE dilution (shown in Fig. 4). Overall, differences in T-cell proliferation in the $\mathrm{T}_{\mathrm{N}}$-depleted memory fractions $(\mathrm{NF})$ co-cultured with autologous versus allogeneic stimulators were lower than those in unmanipulated $\mathrm{CD}^{+}$controls and the $\mathrm{T}_{\mathrm{N}^{-}}$enriched fractions (PF), as shown in Figure 4. In the memory fractions, lower alloreactivity was detected in CD45RA_ NF compared to CD62L_NF (2.5 vs. 3.8\% difference in proliferation). The lowest alloreactivity was shown for CD45RA_NF (2.5\% difference in proliferation), while CD62L_PF resulted in the highest alloreactivity $(28.3 \%$ difference in proliferation, $p<0.05)$. Additionally,
Fig. 3. T-cell responses to ppEBV_EBNA1, ppEBV_Consensus and ppAdV_Hexon detected by IFN- $\gamma$ ELISpot assay after shortterm and long-term in vitro stimulation. Antiviral T-cell responses were determined by target cell-dependent IFN- $\gamma$ ELISpot assay. $\mathrm{CD}^{+} \mathrm{T}$ cells were isolated from PBMCs of 6 healthy blood donors followed by $\mathrm{T}_{\mathrm{N}}$ depletion using CD45RA and CD62L microbeads. EBV-specific (A, B) and AdV-specific (C) T-cell responses detected by IFN- $\gamma$ ELISpot assay after short-term (1 day) and long-term in vitro stimulation (7 days) with antigen-loaded CD3-depleted PBMCs (target cells) loaded with either ppEBV_EBNA1, ppEBV_
Consensus or ppAdV_Hexon $(1 \mu \mathrm{g}$ per peptide $/ \mathrm{mL})$ at an E:T ratio of 1:1. As a control, T-cell fractions were cultured alone in the presence of IL-2, IL-7 and IL-15. Data are expressed as means of 6 donors and were calculated by subtracting the observed values from the control. Memory/negative fractions: CD45RA_NF and CD62L_NF, naïve/positive fractions: CD45RA_PF and CD62L_ PF; spw, spot per well; pp, peptide pool. Asterisks indicate statistically significant differences between the T-cell fractions and short- and long-term stimulation (Mann-Whitney test, ${ }^{*} p<0.05$, ** $p<0.01)$.

(For figure see next page.) 
A

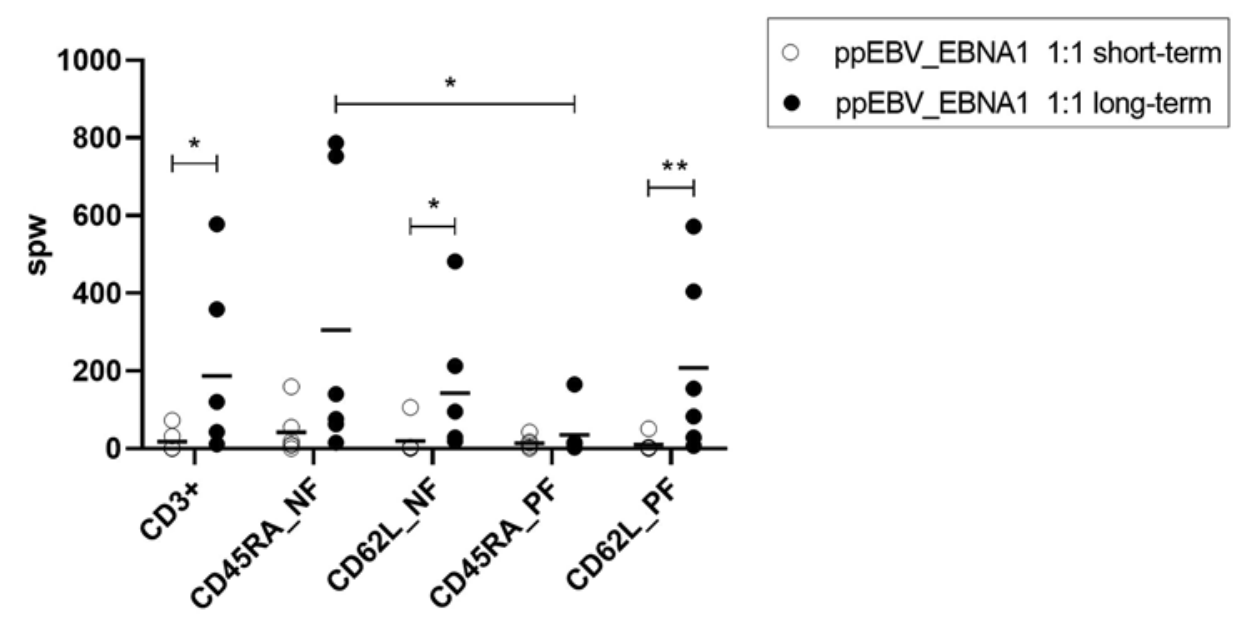

B

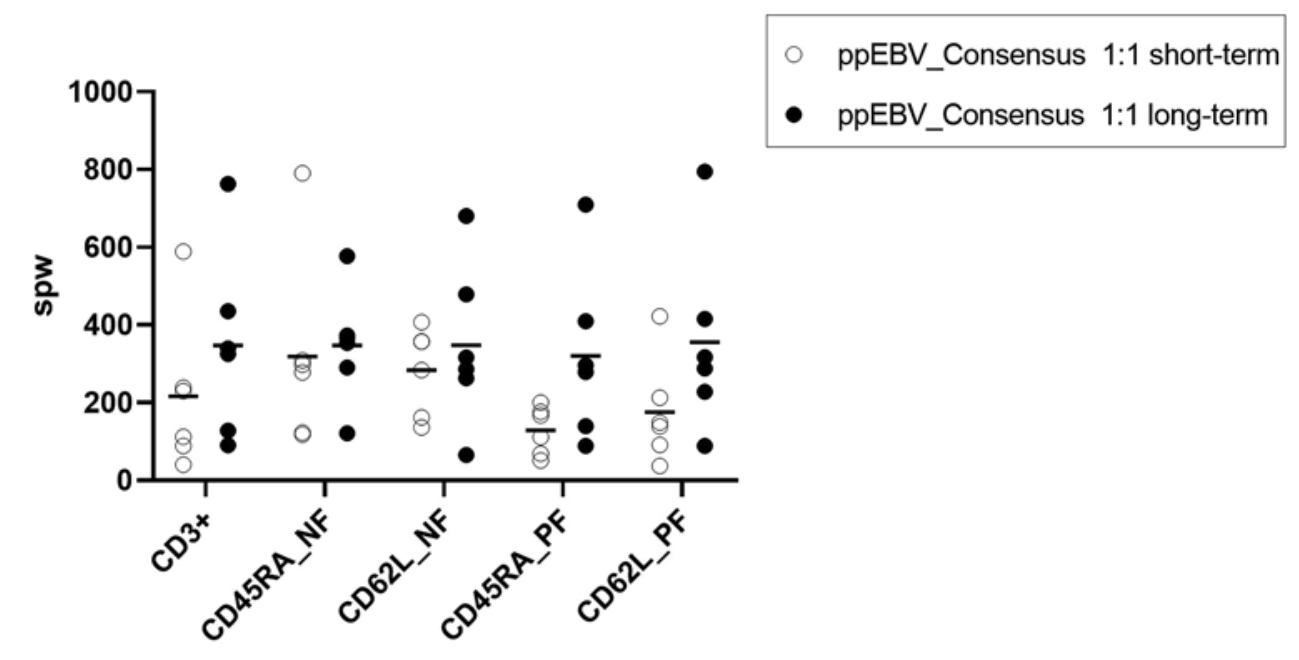

C

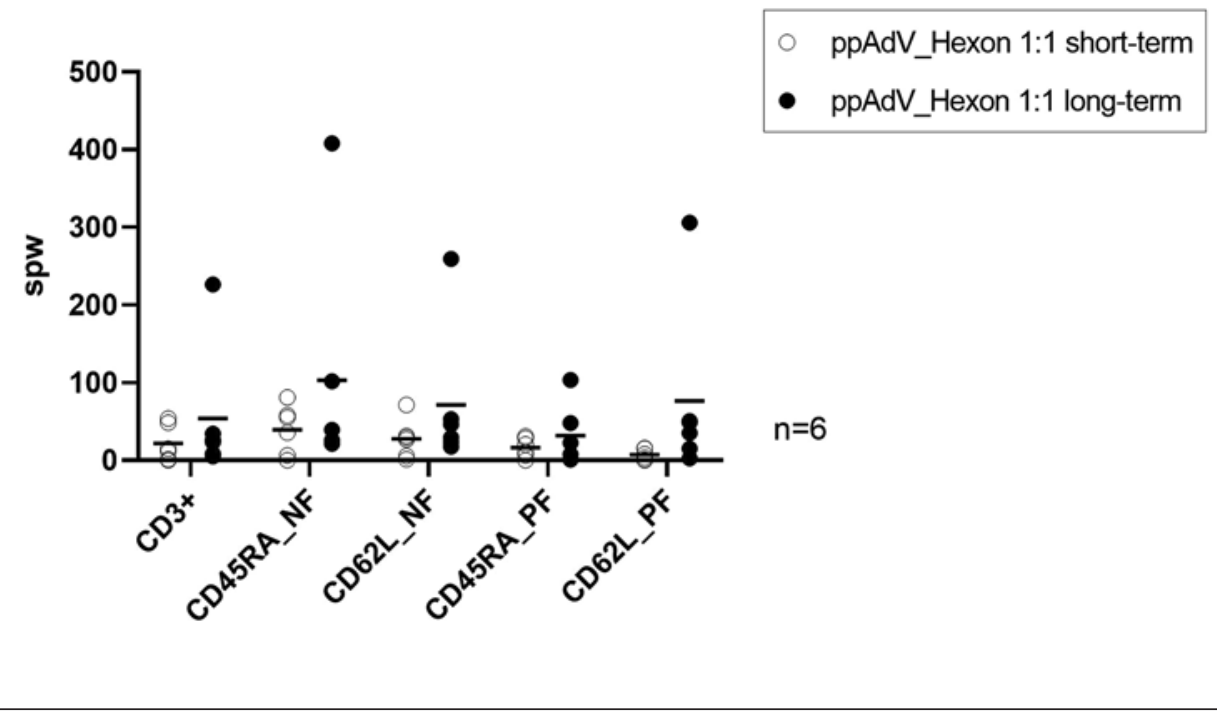




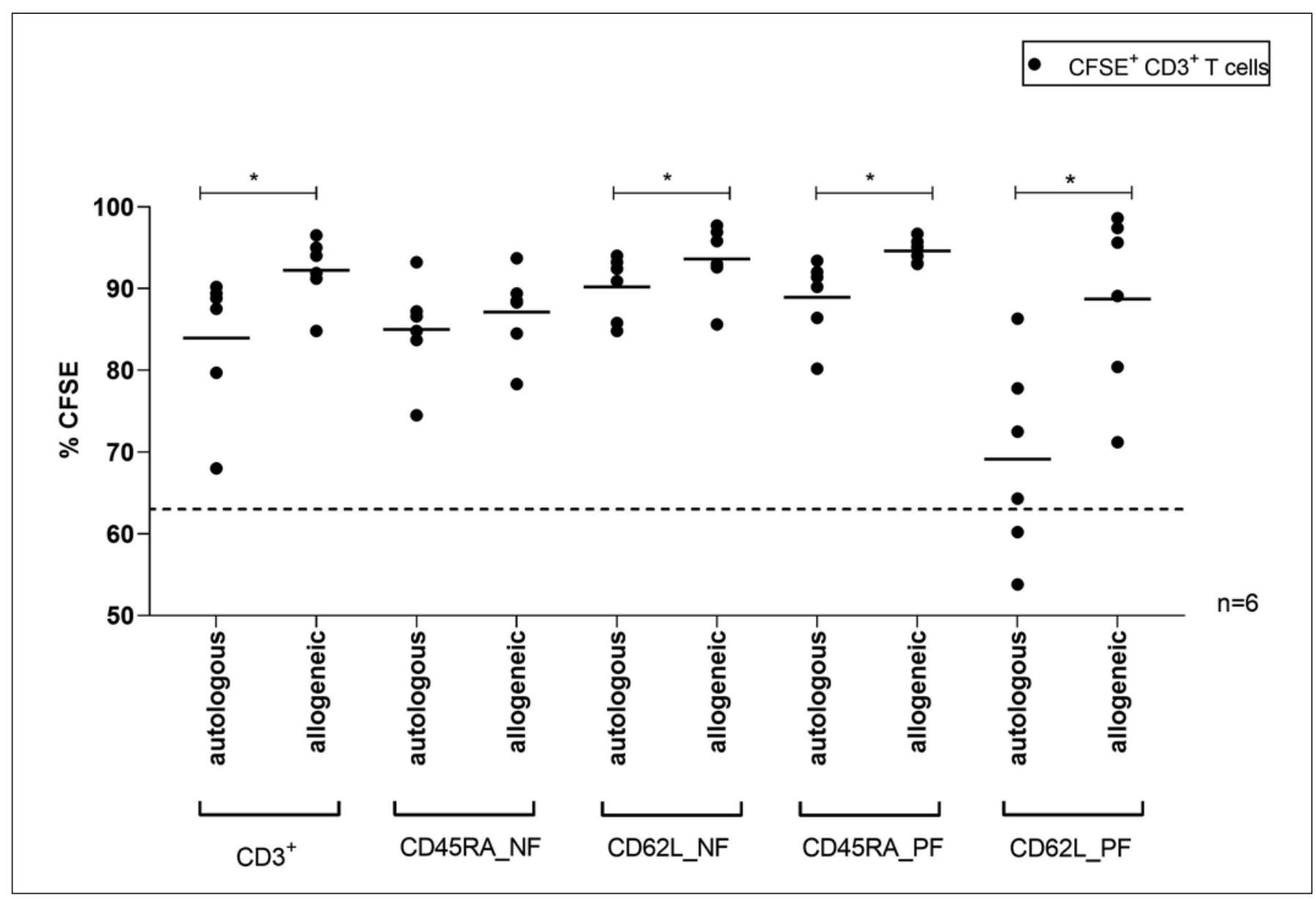

Fig. 4. Attrition of alloreactivity following naïve T-cell depletion. $\mathrm{T}$-cell-mediated alloreactivity measured in the $\mathrm{T}_{\mathrm{N}}$-depleted and enriched fractions (CD45RA_NF/PF and CD62L_NF/PF) by allogeneic mixed lymphocyte reaction (MLR). Effector cells were labelled with carboxyfluorescein succinimidyl ester (CFSE, $4 \mu \mathrm{M}$ ). $1 \times 10^{5}$ CFSE-labelled T cells (responder) were co-cultured with irradiated $(1 \times 30 \mathrm{~Gy})$ autologous or pooled PBMCs (stimulator, from 3 to 5 donors) at an E:T ratio of 1:1 supplemented with IL-2, IL-7 and IL-15. As negative controls, target or effector cells were cultured in the presence of IL-2, IL-7 and IL-15 alone, while T-cell

CD45RA fractions had consistently lower differences in $\mathrm{T}$-cell proliferation between the autologous and allogeneic setting than CD62L fractions (NF: 2.5 vs. $3.8 \%$ and PF: 6.4 vs. $28.3 \%$ difference in proliferation, shown in Fig. 4 ). The naïve fractions exhibited a phenotype shift towards $\mathrm{T}_{\mathrm{CM}}$ and $\mathrm{T}_{\mathrm{EM}}$ following co-culture with HLA-mismatched allogeneic pooled stimulators, highlighting why the alloreactive responses were not significantly higher in the $\mathrm{T}_{\mathrm{N}}$ fractions (shown in online suppl. Fig. S2A-C). The greatest differences between autologous and allogeneic settings were detected in CD45RA_PF compared to CD62L_PF. Furthermore, $\mathrm{CD}^{+}$and $\mathrm{CD}^{+}{ }^{+} \mathrm{T}$-cell subsets displayed similar proportions of proliferation for CD62L fractions (NF/PF) in response to allostimulation but higher proliferation for CD45RA fractions, as reflected by the CD4/ fractions co-cultured with anti-CD3/CD28 beads served as positive control. Background reaction indicated by the mean frequency of proliferating $\mathrm{CFSE}^{+} \mathrm{CD}^{+} \mathrm{T}$ cells in the negative control (effector cells) is shown as dashed line. Memory/negative fractions: CD45RA_NF and CD62L_NF, naïve/positive fractions: CD45RA_ PF and CD62L_PF. Data represent the mean of $n=6$ donors. Asterisks indicate statistically significant differences between autologous and allogeneic calculated using Wilcoxon matched-pairs signed-rank test $(* p<0.05)$.

CD8 ratios following proliferation in the MLR cultures (CD62L_NF: 1.46 vs. 1.44 and CD62L_PF: 2.05 vs. 1.82 ; CD45RA_NF: 4.36 vs. 7.26 and CD45RA_PF: 1.84 vs. 2.88 $\mathrm{CD} 4 / \mathrm{CD} 8$ ratio in the autologous vs. allogeneic setting, shown in online suppl. Fig. S2D).

\section{Discussion}

Adoptive transfer of DLI and VSTs is an effective strategy shown to rapidly restore virus-specific T-cell immunity to prevent or control viral infections following transplantation. DLIs contain memory $\mathrm{T}$ cells against a wide spectrum of pathogens, but therapeutic success is limited by the presence of alloreactive $T_{N}$ capable of causing 
GvHD. Adoptive transfer of VSTs represents a more specific approach which has been successfully applied over the past years $[13,15,16,46]$. Nonetheless, the potential to generate VSTs can be limited if immunodominant epitopes of the target virus are unknown, if antigens required for stimulation and enrichment are not available in good manufacturing practice quality, or if no at least partially HLA-matched seropositive donor with sufficient VST frequencies is available. Alternative strategies for clinicalgrade $\mathrm{T}$-cell production are urgently required to overcome these limitations. Selective depletion of alloreactive $\mathrm{T}_{\mathrm{N}}$ using immunomagnetic CD45RA and CD62L microbeads represents a promising strategy for preserving memory $T$ cells against a broad variety of pathogens while reducing the risk of GvHD. In a previous study, we demonstrated that $\mathrm{T}_{\mathrm{N}}$ depletion with CD62L microbeads was preferable for $\mathrm{CMV}$ due to the presence of $\mathrm{CD} 8^{+} \mathrm{T}_{\mathrm{EMRA}}$ and $\mathrm{T}_{\mathrm{EM}}[26]$. Variable differences in immunophenotypic composition of $\mathrm{T}$-cell fractions between donors led to differences in $\mathrm{CMV}$-specific $\mathrm{T}$-cell responses, indicating that the $\mathrm{T}_{\mathrm{N}}$ depletion strategy should be selected according to the specific T-cell phenotypes mirrored in the donor $[25,26]$. Based on our previous experience, the present study was designed to identify the most suitable strategy for generating $\mathrm{T}_{\mathrm{N}}$-depleted lymphocyte products containing low-frequency functionally active antiviral memory T cells using EBV and AdV as viral models. The results of this study provide comprehensive data on human antiviral T-cell responses against AdV and EBV following $\mathrm{T}_{\mathrm{N}}$ depletion, which indicate that $\mathrm{T}_{\mathrm{N}}$ depletion strategies via CD45RA and CD62L represent feasible alternatives for generating memory $\mathrm{T}$-cell products that will provide a broad, pathogen-specific T-cell repertoire and minimise risk of GvHD.

\section{Complexity of Antiviral T-Cell Responses in Relation to T-Cell Frequencies and Phenotype}

Following long-term in vitro stimulation, CD4/CD8 ratios and immunophenotypic compositions of the various T-cell fractions differed depending on the type of viral antigen used. T-cell fractions stimulated with ppEBV_EBNA1 and ppAdV_Hexon were characterized by a marked increase in $\mathrm{CD} 4^{+} \mathrm{T}$-cell subset and $\mathrm{T}_{\mathrm{EM}}$, which were the most dominant phenotype, particularly in CD45RA_NF. T-cell fractions stimulated with ppEBV_Consensus displayed slightly higher amounts of $\mathrm{T}_{\mathrm{CM}}$ in CD62L_NF and of the $\mathrm{T}_{\mathrm{EM}}$ phenotype in the other T-cell fractions, with higher-level activation of $\mathrm{CD}^{+} \mathrm{T}$ cells; this was essentially caused by HLA class I-restricted epitopes within ppEBV_Consensus. Previous studies consistently report that EBV_EBNA1-specific T cells are mainly $\mathrm{CD}^{+}$restricted and contribute to controlling EBV infection and EBV-associated malignancies [47]. EBV latent-cycle proteins were shown to display a dis- tinct, marked hierarchy of immunodominance for $\mathrm{CD} 4^{+}$ T-cell responses (EBNA1, EBNA3C $\gg$ LMP1, LMP2) and categorical differences with respect to $\mathrm{CD} 8^{+} \mathrm{T}$-cell responses $($ EBNA3C $>$ EBNA1 $>$ LMP2 $\gg$ LMP 1 ) from the same EBV proteins $[47,48]$. Moreover, the slight increase in $\mathrm{CD}^{+} \mathrm{T}$-cell frequency observed following stimulation with ppAdV_Hexon in the present study represented the major responding $\mathrm{T}$-cell population, and the respective healthy adult or convalescent subjects developed longlived $\mathrm{CD}^{+}{ }^{+} \mathrm{T}$-cell responses $[49,50]$. Apparently, these $\mathrm{AdV}$-specific $\mathrm{CD}^{+} \mathrm{T}$ cells are able to recognize conserved antigens and can exhibit cross-reactivity with diverse serotypes $[50,51]$. Our results suggest that products with a higher content of $\mathrm{CD} 4^{+} \mathrm{T}$ cells, such as CD45RA_NF, will be more efficient in providing ppEBV_EBNA1- and ppAdV_Hexon-specific T cells since these are primarily mediated by $\mathrm{CD} 4^{+} \mathrm{T}$ cells. In a clinical study by Triplett et al. [52], CD45RA_NF conferred specific protection against adenoviral colitis, despite reduced use of cidofovir, and additionally reduced EBV reactivation: only 1 of 67 patients developed posttransplant lymphoproliferative disease due to the efficacy of B-cell depletion in this T-cell fraction. In general, the magnitude of the EBV-specific T-cell responses was consistently greater than that of the $\mathrm{AdV}$-specific responses in the same individuals. These differences are likely due to the fact that EBV is a persistent virus that provides chronic stimulation to circulating memory $\mathrm{T}$ cells, while AdV causes non-persistent infections that are cleared by the immune response [52].

\section{A Simple Model to Demonstrate the Magnitude of}

T-Cell Responses of Low-Frequency Antiviral T Cells after Long-Term Stimulation

Reduction in viral loads often correlates with expansion of $\mathrm{T}$ cells that recognize targeted viral antigens $[46,53]$. Therefore, the magnitude of T-cell responses of specific low-frequency antiviral $\mathrm{T}$ cells against ppEBV_EBNA1 and ppAdV_Hexon was measured after short- and longterm in vitro stimulation in this study. Short-term stimulation mainly resulted in no or low T-cell responses in the naïve fractions, and slightly higher responses in the memory fractions. On the other hand, T-cell responses against ppEBV_Consensus were consistently higher responses in all T-cell fractions. These findings are consistent with those of previous reports that highlight the fact that EBV EBNA1-derived epitopes are of low frequency $[54,55]$ and that only about $1-2 \%$ of circulating $\mathrm{T}$ cells are specific for EBV in healthy EBV seropositive individuals [56-58]. Interestingly, following long-term in vitro stimulation, the highest increase in T-cell response, as detected by IFN- $\gamma$ ELISpot assay, was obtained with ppEBV_EBNA1 (up to 4 -fold), and the increase correlated with the cell count; ppEBV_Consensus, on the other hand, resulted in a pro- 
foundly low, marginal difference. These results consistently confirm the high proliferative and differentiation potentials of low-frequency EBV- and AdV-specific memory T cells, which shifted to a more $\mathrm{T}_{\mathrm{EM}}$ phenotype, producing effector molecules that were sufficient to elevate T-cell responses, particularly in CD45RA_NF. These findings are in line with those of other studies reporting that infusions with low frequencies of donor-derived cytotoxic T lymphocytes were able to sufficiently and dynamically expand in vivo, with clinical benefits persisting for more than 3 years [59-61].

\section{Dynamics and Functional Signatures of T-Cell Phenotypes in Antiviral T-Cell Immunity among the Different CD45RA_NF/PF and CD62L_NF/PF Fractions}

The findings of the present study demonstrate that the investigated CD45RA and CD62L depletion strategies deplete different parts of the memory $\mathrm{T}$-cell phenotypes. CD45RA additionally depletes $\mathrm{CD}^{+} \mathrm{T}_{\text {EMRA }}$, while CD62L depletes $\mathrm{T}_{\mathrm{CM}}$. These differences resulted in variable antiviral T-cell responses against different viral antigens in the CD45RA_NF/PF and CD62L_NF/PF. Memory $\mathrm{T}$ cells display diversity in terms of antigenic phenotype, which correlates to their functional capacity. We have shown that EBV_EBNA1 and AdV_Hexon-specific $\mathrm{T}$-cell responses are mainly mediated by $\mathrm{CD} 4^{+} \mathrm{T}_{\mathrm{EM}}$, while $\mathrm{CD}^{+} \mathrm{T}_{\mathrm{CM}}$ and $\mathrm{T}_{\mathrm{EM}}$ are responsible for $\mathrm{T}$-cell responses against ppEBV_Consensus. In a previous study, we observed variable differences in phenotypic composition between donors, which led to differences in CMV-specific T-cell responses and subsequent stratification of donors into donors with expected response and donors with unexpected response [26]. This classification was mainly due to the observed differences in CD45RA fractions. However, our tested donors were not stratified in this manner since the EBV_EBNA1 and AdV_Hexonspecific T-cell responses were mainly observed in CD45RA_NF. For this reason, we conclude that $\mathrm{T}_{\mathrm{N}}$ depletion using CD45RA is suitable for ppEBV_EBNA1 and ppAdV_Hexon due to the presence of $\mathrm{CD} 4^{+} \mathrm{T}$ cells and $\mathrm{T}_{\mathrm{EM}}$ in CD45RA_NF, while depletion with CD62L is beneficial in the case of $\mathrm{CMV}$ due to the fact that $\mathrm{CD} 8^{+}$ $\mathrm{T}$ cells and $\mathrm{T}_{\mathrm{EM}}$ are retained in CD62L_NF [26]. Therefore, clinicians should use a balanced approach to selecting the $\mathrm{T}$-cell phenotype that is most suitable for control of the viral infection in question according to the specific phenotypic composition of the donor.

\section{Attrition of Alloreactivity following Naïve T-Cell}

Depletion with CD45RA and CD62L Microbeads

HLA mismatch antigens are major targets of alloreactive T cells in HLA-incompatible cellular T-cell products; this can trigger severe GvHD and, thus, reduce survival in transplant recipients. The frequency of alloreactive $\mathrm{T}$ cells capable of reacting with any unique allogeneic MHC haplotype represents a substantial proportion of the naïve T-cell repertoire and is estimated to range from 0.1 to $10 \%$ [62-65]. Mouse models revealed that CD $4^{+}$ and $\mathrm{CD}^{+} \mathrm{T}$ cells are capable of mediating lethal GvHD [66]. $\mathrm{T}_{\mathrm{N}}$ caused severe GvHD, $\mathrm{T}_{\mathrm{CM}}$ induced milder GvHD, and $\mathrm{T}_{\mathrm{EM}}$ did not cause significant GvHD [67-70]. However, the relative contributions of $\mathrm{CD} 4^{+}$and $\mathrm{CD} 8^{+}$ naïve and memory $\mathrm{T}$ cells to alloimmune response in HLA-incompatible transplants in humans are still unclear. Here, we used MLR cultures in order to assess and identify T-cell fractions with reduced in vitro reactivity to mismatched HLA. We found significantly higher proliferation in the allogeneic setting compared to the autologous setting for all $\mathrm{T}$-cell fractions with the exception of CD45RA_NF. Essentially, $\mathrm{T}_{\mathrm{N}}$ depletion with CD45RA was more effective in reducing alloimmune T-cell responses than CD62L, which showed variability among the donors. These findings suggest that depletion with CD45RA is preferable for preventing the development of GvHD. These data are consistent with those reported by Distler et al. [71], who compared several markers for $T_{N}$ depletion and found out that CD45RA was more efficient than others, e.g., CD45RO, CCR7 and CD62L. Our results indicate that $\mathrm{CD}^{+}$populations tend to proliferate at slightly higher frequencies in response to allostimulation among the CD62L_PF/NF fractions in both the autologous and the allogeneic setting. It is noteworthy that in our previous analysis, CD45RA_NF had a higher amount of $\mathrm{T}_{\text {reg }}$ cells, which are known to be potent suppressors regulating alloreactive donor $\mathrm{T}$-cell responses [72-75]. Thus, it could be postulated that $\mathrm{T}_{\text {regs }}$ in CD45RA_NF might contribute to the decreased alloreactive $\mathrm{T}$-cell responses. In agreement with a study reported by Teschner et al. [36], $\mathrm{T}_{\mathrm{N}}$ depletion via CD45RA decreased the number of alloreactive $\mathrm{CD}^{+} \mathrm{T}$ cells in CD45RA_NF and, hence, induced lower alloreactivity levels than the starting DLI. Therefore, although $\mathrm{T}_{\mathrm{N}}$ depletion with CD45RA is less effective in $\mathrm{CD}^{+} \mathrm{T}$ cells, it may decrease the overall GvHD induction potential in vivo. Contrary to our expectations, we observed curtailed alloreactivity levels in the $T_{N}$ fractions, particularly in CD62L_PF. Thus, we performed phenotype analysis following MLR culture and found that the $\mathrm{T}_{\mathrm{N}}$ population had substantially decreased and differentiated into effector T lymphocytes, which may explain the aforementioned observation. Indeed, a recent clinical investigation by Bleakley et al. [76] revealed that although $\mathrm{T}_{\mathrm{N}^{-}}$ depleted PBMCs did not reduce the incidence of acute GvHD following infusion, the patients were responsive to corticosteroids and, remarkably, the occurrence of chronic GvHD was 9\% compared to 50\% with T-celldepleted grafts.
Mangare et al. 


\section{Conclusion}

This study demonstrates the feasibility of $\mathrm{T}_{\mathrm{N}}$ depletion using both CD45RA and CD62L immunomagnetic beads and highlights differences between the two approaches. $\mathrm{T}_{\mathrm{N}}$ depletion with CD45RA results in high CD4/CD8 ratios due to enrichment of $\mathrm{CD} 4^{+}$and depletion of $\mathrm{CD} 8^{+}$ $\mathrm{T}$ cells, while $\mathrm{T}_{\mathrm{N}}$ depletion with $\mathrm{CD} 62 \mathrm{~L}$ retains $\mathrm{CD} 8^{+}$ T cells. EBV_EBNA1- and AdV_Hexon-specific T cells are mainly of the $\mathrm{CD} 4^{+} \mathrm{T}_{\mathrm{EM}}$ phenotype; hence, $\mathrm{T}_{\mathrm{N}}$ depletion with CD45RA will be preferable for $\mathrm{CD}^{+}$antiviral $\mathrm{T}$ cells. $\mathrm{T}_{\mathrm{N}}$ depletion with CD62L will be suitable for $\mathrm{CD}^{+}$antiviral $\mathrm{T}$ cells, such as those stimulated with CMV-derived antigens, which are mainly $\mathrm{CD}^{+} \mathrm{T}_{\mathrm{EM}}$; dismally, this occurs with a loss of $\mathrm{T}_{\mathrm{CM}}$. Taken together, our results indicate that CD45RA is more suitable for generating $\mathrm{T}_{\mathrm{N}^{-}}$-depleted products consisting of memory $\mathrm{T}$ cells against ppEBV_EBNA1 and ppAdV_Hexon than CD62L in terms of product purity, T-cell functionality and alloreactivity. This study underlines the need to select precise $\mathrm{T}_{\mathrm{N}}$ depletion strategies according to the immunophenotypic T-cell profile and the CD4/CD8 antigen restriction. This concept will ensure the production of effective lymphocyte products that will provide a broad, pathogenspecific T-cell repertoire and minimise the risk of GvHD. Efficacy and safety enhancement is essential to improving the therapeutic benefit of adoptive immunotherapy and the clinical outcome.

\section{Acknowledgements}

The authors would like to thank Nicole Neumann, Dörthe Rokitta, Sarina Lukis, Elvira Schulde, Sophie Meyer and Bach Uy Vu for their excellent technical assistance.

\section{Statement of Ethics}

The study was approved by the Institutional Review Board of Hannover Medical School (MHH, approval number 3331_2016, 3639_2017).

\section{Conflict of Interest Statement}

The authors declare no conflict of interest.

\section{Funding Sources}

C.M. was supported by the Kenyan-German Postgraduate program in conjunction with DAAD, the Hannover Biomedical Research School (HBRS). This study was funded by the Deutsche Forschungsgemeinschaft (DFG, German Research Foundation), project ID 158989968-SFB 900/B11.

\section{Author Contributions}

C.M. participated in the design of the study, carried out the experiments for T-cell isolation, functionality assays and immunofluorescence staining, performed the data and statistical analysis and drafted the manuscript; S.T.-Z. participated in the design of the study, provided helpful input to overall discussions, data and statistical analysis, and co-wrote the manuscript; A.B. contributed with helpful discussion and helped to draft the manuscript; S.B.R. contributed with helpful discussion and helped to draft the manuscript; A.C.D. contributed with helpful discussion and helped to draft the manuscript; B.M.-K. contributed with helpful discussion and helped to draft the manuscript; R.B., the head of the institute, contributed with helpful discussion and helped to draft the manuscript; B.E.-V. conceived the study and participated in its design and coordination, designed the experiments for T-cell isolation, functionality assays and immunofluorescence staining, participated in the statistical analysis and co-wrote the manuscript.

\section{References}

1 Wingard JR, Majhail NS, Brazauskas R, Wang Z, Sobocinski KA, Jacobsohn D, et al. Longterm survival and late deaths after allogeneic hematopoietic cell transplantation. J Clin Oncol. 2011;29(16):2230-9.

2 Gratwohl A, Brand R, Frassoni F, Rocha V, Niederwieser D, Reusser P, et al. Cause of death after allogeneic haematopoietic stem cell transplantation (HSCT) in early leukaemias: an EBMT analysis of lethal infectious complications and changes over calendar time. Bone Marrow Transplant. 2005;36(9):757-69.

3 Styczynski J, Tridello G, Gil L, Ljungman P, Hoek J, Iacobelli S, et al. Impact of donor Epstein-Barr virus serostatus on the incidence of graft-versus-host disease in patients with acute leukemia after hematopoietic stem-cell transplantation: a study from the Acute Leukemia and Infectious Diseases Working Parties of the European Society for Blood and Marrow Transplantation. J Clin Oncol. 2016; 34(19):2212-20.
4 Long HM, Meckiff BJ, Taylor GS. The T-cell response to Epstein-Barr virus - New tricks from an old dog. Front Immunol. 2019;10: 2193.

5 Baumforth KR, Young LS, Flavell KJ, Constandinou C, Murray PG. The Epstein-Barr virus and its association with human cancers. Mol Pathol. 1999;52(6):307-22.

6 Pagano JS. Epstein-Barr virus: the first human tumor virus and its role in cancer. Proc Assoc Am Physicians. 1999 Nov-Dec;111(6):57380.

7 Serraino D, Piselli P, Angeletti CI, Scuderi M, Ippolito G, Capobianchi MR, et al. Infection with Epstein-Barr virus and cancer: an epidemiological review. J Biol Regul Homeost Agents. 2005;19(1-2):63-70.

8 Iwakiri D. [Mechanisms of Epstein-Barr Virus-Mediated Oncogenesis]. Gan To Kagaku Ryoho. 2015;42(10):1133-6.
9 Lion T, Baumgartinger R, Watzinger F, Matthes-Martin S, Suda M, Preuner S, et al. Molecular monitoring of adenovirus in peripheral blood after allogeneic bone marrow transplantation permits early diagnosis of disseminated disease. Blood. 2003;102(3):111420.

10 Matthes-Martin S, Feuchtinger T, Shaw PJ, Engelhard D, Hirsch $\mathrm{HH}$, Cordonnier C, et al. European guidelines for diagnosis and treatment of adenovirus infection in leukemia and stem cell transplantation: summary of ECIL-4 (2011). Transpl Infect Dis. 2012;14(6):55563.

11 Walls T, Shankar AG, Shingadia D. Adenovirus: an increasingly important pathogen in paediatric bone marrow transplant patients. Lancet Infect Dis. 2003;3(2):79-86.

12 Wold WS, Toth K. New drug on the horizon for treating adenovirus. Expert Opin Pharmacother. 2015;16(14):2095-9. 
13 Leen AM, Heslop HE, Brenner MK. Antiviral T-cell therapy. Immunol Rev. 2014;258(1): 12-29.

14 Arasaratnam RJ, Leen AM. Adoptive T cell therapy for the treatment of viral infections. Ann Transl Med. 2015;3(18):278.

15 Barrett AJ, Prockop S, Bollard CM. Virus-Specific T Cells: Broadening Applicability. Biol Blood Marrow Transplant. 2018;24(1):13-8

16 Casalegno-Garduño R, Schmitt A, Yao J, Wang X, Xu X, Freund M, et al. Multimer technologies for detection and adoptive transfer of antigen-specific T cells. Cancer Immunol Immunother. 2010;59(2):195-202.

17 Fuji S, Kapp M, Grigoleit GU, Einsele H. Adoptive immunotherapy with virus-specific T cells. Best Pract Res Clin Haematol. 2011 24(3):413-9.

18 Geyeregger R, Freimüller C, Stemberger J, Artwohl M, Witt V, Lion T, et al. First-in-man clinical results with good manufacturing practice (GMP)-compliant polypeptide-expanded adenovirus-specific T cells after haploidentical hematopoietic stem cell transplantation. J Immunother. 2014;37(4):245-9.

19 Leen AM, Sili U, Savoldo B, Jewell AM, Piedra PA, Brenner MK, et al. Fiber-modified adenoviruses generate subgroup cross-reactive, adenovirus-specific cytotoxic T lymphocytes for therapeutic applications. Blood. 2004;103(3): 1011-9.

20 Maung KK, Chen BJ, Barak I, Li Z, Rizzieri DA, Gasparetto C, et al. Phase I dose escalation study of naive T-cell depleted donor lymphocyte infusion following allogeneic stem cell transplantation. Bone Marrow Transplant. 2021 Jan;56(1):137-43.

21 Müller N, Landwehr K, Langeveld K, Stenzel J, Pouwels W, van der Hoorn MAWG, et al. Generation of alloreactivity-reduced donor lymphocyte products retaining memory function by fully automatic depletion of CD45RA-positive cells. Cytotherapy. 2018; 20(4):532-42

22 Roy DC, Walker I, Maertens J, Lewalle P, Olavarria E, Selleslag D, et al. ATIR101 administered after T-cell-depleted haploidentical HSCT reduces NRM and improves overall survival in acute leukemia. Leukemia. 2020; 34(7):1907-23.

23 Harari A, Dutoit V, Cellerai C, Bart PA, Du Pasquier RA, Pantaleo G. Functional signatures of protective antiviral T-cell immunity in human virus infections. Immunol Rev. 2006;211:236-54

24 Jackson SE, Mason GM, Okecha G, Sissons JG, Wills MR. Diverse specificities, phenotypes, and antiviral activities of cytomegalovirus-specific CD8+ T cells. J Virol. 2014; 88(18):10894-908.

25 Appay V, van Lier RA, Sallusto F, Roederer M. Phenotype and function of human T lymphocyte subsets: consensus and issues. Cytometry A. 2008;73(11):975-83.

26 Mangare C, Tischer-Zimmermann S, Riese SB, Dragon AC, Prinz I, Blasczyk R, et al. Robust Identification of Suitable T-Cell Subsets for Personalized CMV-Specific T-Cell Immunotherapy Using CD45RA and CD62L Microbeads. Int J Mol Sci. 2019;20(6);1415.

27 Appay V, Dunbar PR, Callan M, Klenerman P, Gillespie GM, Papagno L, et al. Memory
CD8+ T cells vary in differentiation phenotype in different persistent virus infections Nat Med. 2002;8(4):379-85.

28 Almeida JR, Price DA, Papagno L, Arkoub ZA, Sauce D, Bornstein E, et al. Superior control of HIV-1 replication by CD8+ T cells is reflected by their avidity, polyfunctionality, and clonal turnover. J Exp Med. 2007;204(10): 2473-85.

29 Grifoni A, Angelo MA, Lopez B, O’Rourke $\mathrm{PH}$, Sidney J, Cerpas C, et al. Global Assessment of Dengue Virus-Specific CD4(+) T Cell Responses in Dengue-Endemic Areas. Front Immunol. 2017;8:1309.

30 Brien JD, Uhrlaub JL, Nikolich-Zugich J. West Nile virus-specific CD4 T cells exhibit direct antiviral cytokine secretion and cytotoxicity and are sufficient for antiviral protection. J Immunol. 2008;181(12):8568-75.

31 Elong Ngono A, Young MP, Bunz M, Xu Z, Hattakam S, Vizcarra E, et al. CD4+ T cells promote humoral immunity and viral control during Zika virus infection. PLoS Pathog. 2019;15(1):e1007474.

32 Manzke N, Akhmetzyanova I, Hasenkrug KJ, Trilling M, Zelinskyy G, Dittmer U. CD4+ T cells develop antiretroviral cytotoxic activity in the absence of regulatory T cells and CD8+ T cells. J Virol. 2013;87(11):6306-13.

33 Barber DL, Wherry EJ, Masopust D, Zhu B, Allison JP, Sharpe AH, et al. Restoring function in exhausted CD8 T cells during chronic viral infection. Nature. 2006;439(7077):6827.

34 Giannandrea M, Yee M, O'Reilly MA, Lawrence BP. Memory CD8+ T Cells Are Sufficient to Alleviate Impaired Host Resistance to Influenza A Virus Infection Caused by Neonatal Oxygen Supplementation. Clin Vaccine Immunol. 2012;19(9):1432-41.

35 Touzot F, Neven B, Dal-Cortivo L, Gabrion A, Moshous D, Cros G, et al. CD45RA depletion in HLA-mismatched allogeneic hematopoietic stem cell transplantation for primary combined immunodeficiency: A preliminary study. J Allergy Clin Immunol. 2015;135(5): 1303-3.

36 Teschner D, Distler E, Wehler D, Frey M, Marandiuc $\mathrm{D}$, Langeveld $\mathrm{K}$, et al. Depletion of naive $T$ cells using clinical grade magnetic CD45RA beads: a new approach for GVHD prophylaxis. Bone Marrow Transplant. 2014; 49(1):138-44

37 Sallusto F, Lenig D, Förster R, Lipp M, Lanzavecchia A. Two subsets of memory T lymphocytes with distinct homing potentials and effector functions. Nature. 1999;401(6754): 708-12.

38 Bieling M, Tischer S, Kalinke U, Blasczyk R, Buus S, Maecker-Kolhoff B, et al. Personalized adoptive immunotherapy for patients with EBV-associated tumors and complications: Evaluation of novel naturally processed and presented EBV-derived T-cell epitopes. Oncotarget. 2018;9(4):4737-57.

39 Sukdolak C, Tischer S, Dieks D, Figueiredo C, Goudeva L, Heuft H-G, et al. CMV-, EBVand ADV-specific T cell immunity: screening and monitoring of potential third-party donors to improve post-transplantation outcome. Biol Blood Marrow Transplant. 2013; 19(10):1480-92.
40 Bunse CE, Borchers S, Varanasi PR, Tischer S, Figueiredo C, Immenschuh S, et al. Impaired functionality of antiviral T cells in G-CSF mobilized stem cell donors: implications for the selection of CTL donor. PLoS One. 2013; 8(12):e77925.

41 Tischer S, Dieks D, Sukdolak C, Bunse C, Figueiredo C, Immenschuh S, et al. Evaluation of suitable target antigens and immunoassays for high-accuracy immune monitoring of cytomegalovirus and Epstein-Barr virusspecific $\mathrm{T}$ cells as targets of interest in immunotherapeutic approaches. J Immunol Methods. 2014;408:101-13.

42 Fiuza JA, Fujiwara RT, Gomes JA, Rocha MO, Chaves AT, de Araújo FF, et al. Profile of central and effector memory $\mathrm{T}$ cells in the progression of chronic human chagas disease. PLoS Negl Trop Dis. 2009;3(9):e512.

43 Wherry EJ, Ahmed R. Memory CD8 T-cell differentiation during viral infection. J Virol. 2004;78(11):5535-45.

44 Merkenschlager M, Terry L, Edwards R, Beverley PC. Limiting dilution analysis of proliferative responses in human lymphocyte populations defined by the monoclonal antibody UCHL1: implications for differential CD45 expression in T cell memory formation. Eur J Immunol. 1988;18(11):1653-61.

45 Lombardi G, Sidhu S, Daly M, Batchelor JR, Makgoba W, Lechler RI. Are primary alloresponses truly primary?. Int Immunol. 1990; 2(1):9-13.

46 Leen AM, Myers GD, Sili U, Huls MH, Weiss $\mathrm{H}$, Leung KS, et al. Monoculture-derived T lymphocytes specific for multiple viruses expand and produce clinically relevant effects in immunocompromised individuals. Nat Med. 2006;12(10):1160-6.

47 Bickham K, Münz C, Tsang ML, Larsson M, Fonteneau JF, Bhardwaj N, et al. EBNA1-specific CD4+ T cells in healthy carriers of Epstein-Barr virus are primarily Th1 in function. J Clin Invest. 2001;107(1):121-30.

48 Leen A, Meij P, Redchenko I, Middeldorp J, Bloemena E, Rickinson A, et al. Differential immunogenicity of Epstein-Barr virus latent-cycle proteins for human CD4(+) Thelper 1 responses. J Virol. 2001;75(18): 8649-59.

49 Feucht J, Opherk K, Lang P, Kayser S, Hartl L, Bethge W, et al. Adoptive T-cell therapy with hexon-specific Th1 cells as a treatment of refractory adenovirus infection after HSCT. Blood. 2015;125(12):1986-94.

50 Flomenberg P, Piaskowski V, Truitt RL Casper JT. Characterization of human proliferative T cell responses to adenovirus. J Infect Dis. 1995;171(5):1090-6.

51 Perreau M, Kremer EJ. Frequency, proliferation, and activation of human memory T cells induced by a nonhuman adenovirus. J Virol. 2005;79(23):14595-605.

52 Triplett BM, Muller B, Kang G, Li Y, Cross SJ, Moen J, et al. Selective T-cell depletion targeting CD45RA reduces viremia and enhances early T-cell recovery compared with CD3-targeted T-cell depletion. Transpl Infect Dis. 2018;20(1).

53 Keller MD, Bollard CM. Virus-specific T-cell therapies for patients with primary immune deficiency. Blood. 2020;135(9):620-8. 
54 Rajcani J, Szenthe K, Banati F, Szathmary S. Survey of Epstein Barr virus (EBV) immunogenic proteins and their epitopes: implications for vaccine preparation. Recent Pat Antiinfect Drug Discov. 2014;9(1):62-76.

55 Khanna R, Moss DJ, Burrows SR. Vaccine strategies against Epstein-Barr virus-associated diseases: lessons from studies on cytotoxic $\mathrm{T}$-cell-mediated immune regulation. Immunol Rev. 1999;170:49-64.

56 Hislop AD, Taylor GS, Sauce D, Rickinson $\mathrm{AB}$. Cellular responses to viral infection in humans: lessons from Epstein-Barr virus. Annu Rev Immunol. 2007;25:587-617.

57 Tan LC, Gudgeon N, Annels NE, Hansasuta P, O'Callaghan CA, Rowland-Jones S, et al. A re-evaluation of the frequency of CD8+ T cells specific for EBV in healthy virus carriers. J Immunol. 1999;162(3):1827-35.

58 Callan MF, Tan L, Annels N, Ogg GS, Wilson JD, O'Callaghan CA, et al. Direct visualization of antigen-specific CD8+ T cells during the primary immune response to Epstein-Barr virus In vivo. J Exp Med. 1998;187(9):1395402.

59 Sili U, Leen AM, Vera JF, Gee AP, Huls H, Heslop HE, et al. Production of good manufacturing practice-grade cytotoxic T lymphocytes specific for Epstein-Barr virus, cytomegalovirus and adenovirus to prevent or treat viral infections post-allogeneic hematopoietic stem cell transplant. Cytotherapy. 2012;14(1): 7-11.

60 Uhlin M, Gertow J, Uzunel M, Okas M, Berglund S, Watz E, et al. Rapid salvage treatment with virus-specific T cells for therapyresistant disease. Clin Infect Dis. 2012;55(8): 1064-73.
61 Keller MD, Darko S, Lang H, Ransier A, Lazarski CA, Wang Y, et al. T-cell receptor sequencing demonstrates persistence of virusspecific $T$ cells after antiviral immunotherapy. Br J Haematol. 2019;187(2):206-18.

62 Ashwell JD, Chen C, Schwartz RH. High frequency and nonrandom distribution of alloreactivity in T cell clones selected for recognition of foreign antigen in association with self class II molecules. J Immunol. 1986;136(2): 389-95.

63 Heeger PS. T-cell allorecognition and transplant rejection: a summary and update. Am J Transplant. 2003;3(5):525-33.

64 Suchin EJ, Langmuir PB, Palmer E, Sayegh $\mathrm{MH}$, Wells AD, Turka LA. Quantifying the frequency of alloreactive $\mathrm{T}$ cells in vivo: new answers to an old question. J Immunol. 2001; 166(2):973-81.

65 Sherman LA, Chattopadhyay S. The molecular basis of allorecognition. Annu Rev Immunol. 1993;11:385-402.

66 Korngold R, Sprent J. T cell subsets and graftversus-host disease. Transplantation. 1987; 44(3):335-9.

67 Chen BJ, Deoliveira D, Cui X, Le NT, Son J, Whitesides JF, et al. Inability of memory $\mathrm{T}$ cells to induce graft-versus-host disease is a result of an abortive alloresponse. Blood. 2007;109(7):3115-23.

68 Chen BJ, Cui X, Sempowski GD, Liu C, Chao NJ. Transfer of allogeneic CD62L- memory T cells without graft-versus-host disease. Blood. 2004;103(4):1534-41.

69 Dutt S, Tseng D, Ermann J, George TI, Liu YP, Davis CR, et al. Naive and memory T cells induce different types of graft-versus-host disease. J Immunol. 2007;179(10):6547-54.
70 Zheng H, Matte-Martone C, Jain D, McNiff J, Shlomchik WD. Central memory CD8+ T cells induce graft-versus-host disease and mediate graft-versus-leukemia. J Immunol. 2009;182(10):5938-48.

71 Distler E, Bloetz A, Albrecht J, Asdufan S, Hohberger A, Frey M, et al. Alloreactive and leukemia-reactive $\mathrm{T}$ cells are preferentially derived from naive precursors in healthy donors: implications for immunotherapy with memory T cells. Haematologica. 2011;96(7): 1024-32.

72 Beres AJ, Drobyski WR. The role of regulatory $\mathrm{T}$ cells in the biology of graft versus host disease. Front Immunol. 2013;4:163.

73 Brunstein CG, Miller JS, Cao Q, McKenna DH, Hippen KL, Curtsinger J, et al. Infusion of ex vivo expanded $\mathrm{T}$ regulatory cells in adults transplanted with umbilical cord blood: safety profile and detection kinetics. Blood. 2011;117(3):1061-70.

74 Di Ianni M, Falzetti F, Carotti A, Terenzi A, Castellino F, Bonifacio E, et al. Tregs prevent GVHD and promote immune reconstitution in HLA-haploidentical transplantation. Blood. 2011;117(14):3921-8.

75 Mathew JM, Voss JH, McEwen ST, Konieczna I, Chakraborty A, Huang X, et al. Generation and Characterization of Alloantigen-Specific Regulatory T Cells For Clinical Transplant Tolerance. Sci Rep. 2018;8(1):1136.

76 Bleakley M, Heimfeld S, Jones LA, Turtle C, Krause D, Riddell SR, et al. Engineering human peripheral blood stem cell grafts that are depleted of naïve $\mathrm{T}$ cells and retain functional pathogen-specific memory T cells. Biol Blood Marrow Transplant. 2014;20(5):705-16. 